\title{
UNDERPREPAREDNESS IN SOUTH AFRICAN HIGHER EDUCATION: A LIMITED TEST OF THE ENGLISH GRAMMAR AWARENESS OF FIRST-YEAR UNIVERSITY STUDENTS
}

\author{
J. Moyo \\ Department of English Studies \\ The University of South Africa \\ Pretoria, South Africa \\ e-mail: moyoj@unisa.ac.za / https://orcid.org/0000-0002-4317-5674
}

\section{ABSTRACT}

This quasi-experimental study, limitedly, explores the level of English grammar awareness as a potential partial indicator of "underpreparedness" in a population of first-year students doing an English for Academic Purposes (EAP) module in a South African university. This is done by comparing the mean test scores and linguistic errors in two slightly different but equivalent partsof-speech grammar test components in the assignment and supplementary examination scripts of two naturally-occurring subpopulations of the EAP population. Members of the EAP population were in the tests required to correct authentic text parts that had been morphologically and syntactically corrupted for correction. The statistical and linguistic error analyses returned a higher mean test score and a bigger correct-incorrect response ratio for the assignment script sample (the A-Sample) than for the supplementary examination script sample (the SE-Sample). These results suggested, firstly, that extraneous variables were responsible for the variation in the sample test performances, and, secondly, that the grammar instruction, testing and error correction treatments had probably had negligible to no effect at all. The error analysis points to the inadvisability of the inclusion of peripheral grammatical categories such as adverbs in textual modifications for editing as they may not offer optimal opportunities for the exploitation for instructional purposes of the meaning potential of syntactic structures. The grammar instruction observation data showed that a majority of the SE-Sample participated with apparent interest and enthusiasm, thereby suggesting that they viewed the grammar instruction as useful. The observation data also contained a case of resistance to grammar instruction by an older student with a different background to the majority EAP population.

Keywords: underpreparedness, articulation gap, grammatical awareness, form-focused instruction, pedagogical grammar, pedagogic task, error analysis

\section{INTRODUCTION}

The Council for Higher Education (CHE) released in 2013 a report titled A proposal for undergraduate reform in South Africa: The case for a flexible curriculum structure, in which it classifies the factors affecting performance in higher education into material (mostly 
socioeconomic), affective (mostly psychosocial), and academic (mostly didactic and pedagogical) factors, the last of which it regards as a key set of factors (CHE 2013, 55-57). The report argues that the academic factors in particular cause the two impediments to success in higher education known as "underpreparedness" and the "articulation gap". The CHE posits that underpreparedness is caused by unsatisfactory learning outcomes, and by the system design problem of an articulation gap, by which high school education does not, even for the best achiever learners, start ideally where higher education begins. The CHE $(2013,68)$, then, proposes that, instead of blaming the school system and underpreparedness for poor higher education outcomes, higher education institutions should put programmes in place to address underpreparedness. Subsequently, South African (SA) universities were given an opportunity to redesign, or modify, their learning programmes for re-alignment with, and re-registration on, the new Higher Education Qualification Sub-Framework (HEQSF), the top-most component of the expanded, three-sub-framework and ten-level National Qualification Framework (NQF). Because universities have operational autonomy in curriculum design, within structural constraints, of course, the university of focus (the research university henceforth), included a separate (rather than integrated) and compulsory English language and communication skills and literacies foundational learning module (FLM) it has called English for Academic Purposes (EAP), an English-for-Specific Purposes (ESP) module with a distinct grammar component. Since grammar is a challenging subject to teach, especially to older students, who may find it difficult or irrelevant, or find the traditional methods of teaching it boring and unchallenging, teachers should always be watching their practice, and their students' reactions to it, with a view to continuous improvement and responsiveness. I explore in this study what first-year university diploma students' performances and linguistic errors in a limited parts-of-speech English grammar test may imply about "underpreparedness" in SA higher education.

\section{STUDENTS' GRAMMATICAL AWARENESS: PRAXIS AND THEORY}

Many new students seem to present at SA universities with low levels of grammatical awareness in English, the language of tuition in the majority of SA universities, as evidenced by their output or production, especially in writing exercises, of linguistic constructions that are not grammatically well-formed. For instance, many would start responses to questions such as What is deadnaming? without the pronominal it in the initial sentence position, and thus with Is $a \ldots$ instead of It is $a \ldots$, and sometimes not even capitalising the $i$ in the $i$ s they have put in the sentence-initial position. They would produce one-word non-statements, such as by writing just Recall when the intention is clearly to say the imperative Recall something, or by writing just Paraphrase when the expectation is for a predication, that is, for the writer to say something 
about the subject Paraphrase in a definitional declarative statement. From my experience, incomplete statements, run-on sentences, comma splices, non-capitalisation of the personal pronoun $I$ and proper nouns or names, and arbitrary capitalisation have been common occurrences in the written work of some of the university students that I have taught.

They would also use pronouns without clear antecedents, such as in ... are now using this strategy, when the idea of a strategy has not been, or does not get, introduced in the preceding or following text, and cannot be recovered from the situational context, with the result that the reader is forced to ask "What or which strategy?" They would get the answers wrong if you asked them for the past tenses of the modal verbs will, can and shall, and for the synonyms or antonyms of words such as abolished, perceived, oppose and evolved; just as they would if you asked them to attach the correct affixes, as directed by the parenthesised semantic clues next to words such as the following: hope (without hope), hope (present participle), value (remove value), spell (incorrectly spell), grand (superlative).

At least two explanations would be plausible for the previously described inability of the students: they could be unfamiliar with the pedagogical grammar terms, and so could not be expected to answer questions on concepts that they hardly knew; or they might not be able to exploit the meaning potential provided by a syntagmatic analysis of the textual context, if provided, which analysis does not necessarily require knowledge of technical pedagogical grammar terminology (competence) if one is proficient (able to speak and write) in the language. Native-speaker English language learners (ELLs) would perhaps not experience the same difficulties, even if they did not know the pedagogical grammar terminology, because of the affordance provided by the postulated concept of a naturally developed "mother tongue intuition", which helps them to recognise and avoid lexico-grammatically "ill-formed" and "unidiomatic" structures. For non-native ELLs, or English as a Second Language (ESL) learners, a similar defence and affordance, given the theoretical name grammatical awareness, sensitivity or consciousness, has to be explicitly and actively cultivated in instructional contexts, particularly if the ESL learners can be categorised as "older learners" (Long 1997; Ellis 2016, 407). Therefore, if ESL learners fail to employ meaning-based and grammar-based systems to answer questions with clues in both the meaning and the grammatical systems, there is a high probability that they lack grammatical awareness, in which case their reading (input) and writing (output) ability may be negatively affected, which could also negatively influence their learning of language and technical concepts (intake). In this event, they need comprehensible input (Krashen 1982, 20) and pushed output (Swain 2007) language learning tasks, the latter (output), most importantly, to notice the gaps in their knowledge of the grammatical system and its implications for meaning-making in communication. 
So, how important, if at all, is grammatical awareness to reading, writing and learning? Error Analysis (EA) in Second Language Acquisition and Learning (SLA) has long attempted to answer this question through the broad identification and classification of language errors into local and global errors. Local errors are considered to be systematic deviations from standard language use that have minimal negative impact on communication, while global errors are considered to be systematic deviations with distortive effects on meaning (Hendrickson 1976, 3; Burt 1975, 56-57). Local errors involve noun and verb inflections, and the use of articles, prepositions, and auxiliaries; whereas global errors involve wrong word order in a sentence; missing, wrong or misplaced connectors; and the overgeneralising of syntactic rules (Burt 1975, 56-57; Touchie 1986, 76). Errors (competence errors) are distinguished from mistakes (performance errors) and characterised as systematic in that they issue from fundamental language learning and acquisition issues that include wrong pedagogy, or no pedagogy at all, instead of being just slips in performance that may be attributed to performance anxiety. As such, they are an integral and expected part of language development, which is treated by, amongst other means, "error correction treatment", over the short term, and perhaps with unsatisfactory effects, and maybe more successfully by long-term instructional strategies and techniques.

What is tricky about errors in the SA context is when they present in older ELLs, such as university students, who are expected, because of at least nine years of learning English, or in English, to have overcome them. In this regard, it is argued in language teaching that older ELLs who exhibit evidence of a lack of grammatical awareness will draw benefit from direct and intentional instruction in grammar to fix the errors. The issue of contention has been whether grammar should be taught as a formal system, as in traditional language didactics, or as communication, as in the processes of meaning-making in the different specialist discourses of academia, professions or occupations (Basturkmen 2017, 2), what is called Focus-onMeaning (FonM) instruction in English for Specific Purposes (ESP), the dominant English Language Teaching (ELT) approach in universities. Basturkmen $(2017,10)$ argues for the use of Form-Focused instruction (FFI) and materials, the absence of which she noticed in the teaching of the receptive skills of reading and listening, in one example. In ESP, FFI materials should come in the form of language descriptions, based on which a kind of pedagogical grammar is devised that could be employed to direct focus on the necessary discoursal and lexicogrammatical aspects, with the links in them being primary, that is, the link between the grammatical form and the meaning. However, many ESP designs show evidence of "carrier content drift", whereby the content of the specialist discipline replaces the language to be taught, particularly if the ESP practitioner is not a language specialist. Other social factors, such 
as the historical power structure in society, could also be responsible for an absence of language content, not to mention the grammar, in putative language courses. In South Africa, where the system has just barely been accommodating to the needs of ESL learners, university ESP-type programmes employ a mixture of approaches from ESL and native speaker ELT (Dudley-Evans and St. John 1998, 37). However, with a predominantly non-native ELL population, and a history in education of prioritising English- and Afrikaans-speaking population groups, deliberate steps need to be taken to ensure that the language needs of the ESL learners are not overwhelmed by those of the privileged native speaker population groups. English programmes exclude or do not give the necessary attention to grammar even when learners have expressed the need for it, particularly the need for grammar feedback and error correction treatment (Huang 2011, as cited by O’Neill and Russell 2019, 43). Schug and Le Cor $(2017,89)$ have suggested that some learners found traditional grammar content more useful than specialised ESP content. Therefore, responding efficiently to the needs of all ELLs will require a fine balancing of approaches that prioritise meaning and those that focus on grammar, as recommended for older ELLs (Ellis 2016, 413-414), particularly when a lack of knowledge of grammar may constitute a critical barrier to meaning-making in text reception and production.

Form-focused instruction (FFI) is the current trend in English Language Teaching (ELT) that is focused on attempting to include the teaching of grammar in non-native ELT. Ellis (2016, 406) credits the earliest use of the term in the ELT literature, possibly in 1988 and 1991, to Michael Long. According to Ellis (2016, 406), Long initially distinguishes between Focus-onForm (FonF) and Focus-on-Forms (FonFS) "second language teaching approaches", but has by 1997 added a third approach known as Focus-on-Meaning (FonM). Long (1997) initially draws solid lines between the three approaches but analogises FonFS to the traditional structure- and rule-based way of teaching the grammar of a language based on a synthetic syllabus, while he describes FonM as teaching grammar in the indirect, implicit and "incidental" manner that has come to symbolise communicative language teaching (CLT). For some reason, it is the distinction between FonFS and FonF that has attracted more engagement, resulting in Ellis (2015, 10) cautioning against the treatment of the distinction as "oppositional", while expressing the desirability of a curriculum that incorporates both approaches. Ellis $(2016,411)$ eventually advocates for an approach to FonF that marries the features associated with FonFS with those associated with FonF, which he describes as:

"occurring[ing] in activities where meaning is primary but attempts are made to attract attention to form. Thus, it is not an approach but rather a set of techniques deployed in a communicative context by the teacher and/or the learners to draw attention implicitly or explicitly and often briefly to linguistic forms that are problematic for the learners. The focus-on-form may be pre-planned 
and thus address a pre-determined linguistic feature (s) or it can be incidental as a response to whatever communicative or linguistic problems arise while learners are primarily focused on meaning. Focus-on-form activities can be interactive or non-interactive and involve both production and reception. They can be found in both explicit and implicit approaches to language teaching. They can also occur before a communicative task is performed or while it is being performed."

Eventually, it all becomes sort of confusing when the distinction between FonF, FonFS, and FFI all seem to collapse under the label FonF, but that is where we are currently, which has resulted in FonF and FFI being somewhat interchangeable. The FonF or FFI approach, which is preferred in task-based language teaching, championed by both Long (1997) and Ellis (2017), now employs pedagogic tasks and form-focused materials, which Basturkmen $(2017,10)$ describes in ESP as "materials to help learners notice discourse or grammar features in specialist language use".

\section{RESEARCH DESIGN AND METHODOLOGY}

\section{The population and the non-equivalent samples}

The two biased study samples consisted of 25 assignment and 43 supplementary examination scripts. These scripts belonged to two naturally-occurring samples of a population of first-time entering diploma students registered for English for Academic Purposes (hereinafter the EAP population), a ten-credit language and communication skills semester module at the university of interest. The EAP population was over the semester tested on the module content with four credit-bearing assessment types in the following sequence: a take-home assignment, a test, the main summative examination and a supplementary summative examination for candidates who obtained a score of between 44 per cent and 48 per cent in the main summative examination where the minimum pass mark was 50 per cent, which was the pass mark for all tests and assignments. The assignment script sample (the A-Sample) belonged to the group I taught after they wrote the first assessment, the take-home assignment, in March of 2019, which is also referred to as the A-Sample. The supplementary examination sample (the SE-Sample) was from the group that wrote the supplementary examination in June of 2019, which comprised students taught by my colleagues, which is also referred to as the SE-Sample. The two assessments were chosen because they were the first and the last methods of assessment in Semester 1 of 2019, between which there were grammar instruction and testing, naturally simulating the process of a pretest, an intervention, and then a posttest. Furthermore, I had calculated that the SE-Sample presented a higher probability of a sizeable number of language errors than the main examination group, which explains the characterisation of the SE-Sample as a biased sample 
that excluded members of the EAP population who had passed the main examination. The two samples, the majorities of which were ESL learners, were different and non-equivalent in a number of ways, including not being taught by the same lecturers and being exposed to different amounts of instruction and testing by the time of the tests in this study; but they were, however, similar in a fundamental way, for this study, which is that they were both samples of the same EAP population exposed to (standardised) grammar instruction at different but linear times, hence the A-Sample's test score can be treated as a pretest score and that of the SE-Sample as a posttest score under the circumstances. In this sense, the groups were similar to one group that was tested at two points, before and after the grammar instruction.

\section{A description of the form-focused test materials}

The grammatical knowledge taught and tested involved parts of speech, quasi-text-editing and reading comprehension tasks presented as form-focused pedagogic materials created from two authentic texts (see Table 1 and Table 2). From an ESL perspective, the materials could also be described as forced-output materials for forcing EAP students to notice and confront the limits of their grammatical and linguistic knowledge (Swain and Lapkin 1995, 373). The tasks selected - text-editing (error correction), text comprehension, and grammar and text relations feature in Weidemann's (2019, 40-41) typology of language assessment tasks for academic literacy in South Africa.

Both texts were authentic in that they had not been produced for language teaching. The A-Sample text was an excerpt from an unpublished essay I had written as a contribution to national debates on curriculum options in South Africa, while the SE-Sample text was extracted from an online newspaper article. However, the transformation of the materials through parenthesised metalinguistic (pedagogical grammar) clues and input (typographical) enhancement by means of boldface lettering of the targetted forms to increase their noticeability by test-takers (Sharwood Smith 1993; Pam and Karimi 2016, 1122; and their application in a pedagogical situation, make the materials pedagogic materials and the tasks pedagogic tasks, as defined and distinguished by Ellis $(2017,508)$ from real-world tasks that are not modified for teaching purposes. The reference quasi-editing acknowledges these transformations. Although Lee and Huang (2008) theorised interference between the meaningfulness of forms and the use of input enhancement features, Winke (2013) contradicts this finding and concludes that the input enhancement features in her study produced the noticing of target forms, as originally intended by the originators of the concept, not interference with communication. 
Table 1: The A-Sample's test

Substitute the grammatically correct forms of the bolded words according to the clues provided in the
brackets. In certain cases, provide the word required. Write just the number and the correct answer.

An (1.1 noun form of investigate) of South Africa's (1.2 write National curriculum statement as a proper noun) and its subsequent amendments and addenda will reveal that South Africa has adopted a socioeconomic efficiency curriculum model (1.3 past participle of underpin) by Outcomes-Based Education. This curriculum model (1.4 third-person singular form of view) education as being in the service of social and economic development issues, and as a transmitter of skills and not (1.5 adverb form of necessary) of knowledge. To explain this model, one might, for example say, "we teach our learners what we teach them so that they will develop civil society, in general, and the economy, in particular, with economic development having a (1.6 an adjective formed from determinism) role on social development." Some of the obvious socio-economic problems that education is supposed to deliver solutions to, according to this curriculum model, are poverty, (1.7 the negative form of employment). Clearly, this curriculum (1.8 the possessive form of model) purpose is to train the people. But is it also not to form the mind? (1.9 a demonstrative pronoun) who have been following education from long ago enough will know that just as business interests have been looking for an entry into and domination of the education system, so there has been a long-running struggle to keep business interests out of education. For a long time, it was frowned upon to teach any educational programme for the express purpose of (1.10 present participle of make) money or to teach any learner how to become an entrepreneur. (10 words)

The samples, as members of the EAP population, were required to transform these texts back to grammaticality and meaningfulness after ten individual words in either text were morphologically modified (corrupted) and/or syntactically omitted to cause local errors (local errors were preferred for reasons of recoverability of textuality), so that the students would have to read the text, notice the modifications as errors, and then be prompted to correct them, and probably cause further errors in so doing, which errors would then be analysed. The modifications were of two kinds: morphological corruptions, repairs of which required invoking some knowledge of inflectional and derivational morphology; and syntactic omission modifications, which required the insertion of the correct syntactically omitted word to repair.

Table 2: The SE-Sample sample's test

Substitute the grammatically correct forms of the bolded words according to the clues provided in the brackets. In certain cases, provide the word required. Write just the number and the correct answer.

Youth unemployment in SA a "human catastrophe", says Nobel laureate By CHANTALL PRESENCE

Cape Town - Nobel laureate Paul Romer on Monday described South Africa as an "economic disappointment", (2.1 present participle of cite) the high levels of unemployment among the (2.2 the possessive case of country) youth, calling it a "human catastrophe".

"It's a (2.3 an adverb of emphasis) hard story because there was this political miracle in this country which was then followed by economic disappointment and the thing I would point to is not so much the outsiders, but the under-(2.4 complete this concept by inserting a noun form of utilise) of human talent in South Africa," Romer said. He was part of a panel discussion in Cape Town at the ( 2.5 the ordinal form of the word four) annual meeting of (2.6 rewrite new development bank (NDB) as a proper noun) in Cape Town.

The NDB is a multilateral finance institution established by the BRICS bloc of countries - Brazil, Russia, India, China and South Africa. Romer told delegates (2.7 a conjunction) South Africa should not wait for educational reform but should (2.8 a correct adverb) get more people into jobs. "To have such extraordinary high unemployment levels especially among young people ... this is just a catastrophe for the future of this country," he said. "Wages grow (2.9 a preposition) years on the job, people learn on the job so a system that denies 
people a chance to have a job ... this is just a waste of human talent and it's just a (2.10 the present participle of crush) mistake for the people involved." Romer was a co-recipient of the 2018 Nobel memorial prize in economic sciences and was also at one stage a chief economist at the World Bank.

Text source: IOL News. Available from https://www.iol.co.za/news/south-africa/western-cape/youth-

unemployment-in-sa-a-human-catastrophe-says-nobel-laureate-20444514

The pedagogic task was designed to provide the test-takers an opportunity to link the grammatical form and the meaning of the text, which rendered this task an explicit, pre-planned, focus-on-form, productive and receptive language task that focused on a number of taught linguistic units. The textual context would give learners who did not possess knowledge of the parenthesised metalanguage clues an opportunity to get the answers correct through exploiting the meaning potential of syntax through syntagmatic analysis, while paradigmatic analysis was also possible through the substitution or replacement of forms in meaning-based suitability tests. It was critical, however, that the syntactic omission and morphological modifications introduced into the texts for editing retained some textual recoverability, particularly of the type called structural recoverability (Quirk et al. 1985, 861), which is the potential for recoverability of omitted (or modified) language forms through knowledge of grammatical structure, not of the situational context.

\section{The grammar instruction and the error correction treatment}

Before the assignment and the supplementary examination, the EAP population had been given different amounts of explicit, standardised and a priori grammar instruction (not based on needs analysis) as part of the implementation of the programmatic pedagogical content of the module. The grammar instruction for the A-Sample was carried out by myself, the researcher in this study, and by my colleagues for the SE-Sample. It consisted of FonF, FonFS and FonM "exercises", "activities" and "tasks". It started with inductive instruction and practice on the rules of structural grammar governing the eight main parts of speech, and proceeded to basic English sentence types, short text-based classroom exercises on the parts of speech in the textual context, which the test materials in Table 1 and Table 2 reflect, and ended with reading comprehension over the whole Semester. The exercises started with a teacher-led, knowledgeand skill-building phase, and culminated in a learner-led, knowledge- and skill-consolidation phase consisting in learner group and individual work. Corrective feedback or error correction treatment was provided during the pre-teaching and after the grading of the assignment. The attitudes of the EAP students were also observed during grammar instruction, mainly to determine superficial resistance to, or enthusiasm for, the lessons. 


\section{The methods, procedures and data analysis}

Pre-existing numeric (quantitative) and textual (qualitative) data were collected after ethical clearance approval in November of 2019, and then processed and analysed on SPSS Version 25. The data were on the dependent variable, which was student performance on the parts-ofspeech grammar components in the take-home assignment, written and graded in March of 2019, and in the high-stakes venue-based and proctored summative supplementary examination, written and graded in June of 2019. Data were also collected on the independent variable, the grammar instruction, or intervention, which preceded the two assessments. Individual student repairs of the errors were analysed for grammatical well-formedness, and coded as either "correct" or "incorrect"; and the frequency distributions thereof were computed. The overall test performances of the two samples were compared by means of the mean test score and the standard deviation. The possible influence of the unequal sample sizes on the means was assessed through drawing an SPSS-randomised sample of 25 (henceforward the SESubsample) from the bigger SE-Sample and comparing its mean to that of the A-Sample.

Given the previously described quasi-experimental pretest-posttest design, and all things being equal, the mean test score for the SE-Sample was expected to be higher than that of the A-Sample if the grammar instruction and error correction treatments described in the previous subsection, had had some effect. The SE-Sample was considered a more internally valid measure of the limited grammatical awareness because of the controlled conditions (by proctoring, among other measures) of the high-stakes supplementary examination.

The test responses were then subjected to a qualitative quasi-statistical error analysis, wherein the errors in them were identified, described, explained, and evaluated and corrected. Error analysis data were categorised into expected responses, grammatically incorrect responses, crossed-out responses and no-responses. Grammatically incorrect responses were further subdivided into the subjective proximal set, related set and random set. Putative words, or non-words, were included in these categories but marked with italicised bolding.

\section{RESULTS AND DISCUSSION}

\section{Descriptive statistics}

The statistical analysis returned, perhaps against expectations, a higher mean test score for the A-Sample (7.44 of 10 , or $74.4 \%$ ) than for the SE-Sample (4.31 of 10 , or $43.1 \%)$. The SESubsample registered a mean of 4.44 (median: 4.00; standard deviation: 1.22), which, just like the mean of the SE-Sample, can be rounded down to 4.00 , the value of the median in both 
samples. This validates the probability of the true sample mean test score being in the region of 4.00, which is below 5.00, the module EAP's passing threshold of 50 per cent. Correct responses ranged from a minimum of 11 to a maximum of 25, while incorrect responses ranged from 0 to 14 for the A-Sample (See Table 3).

The most incorrect responses by the A-Sample were to the item requiring deriving an adjective form from the noun determinism (14), followed by that which required the inflection of the verb view (12) into its third-person singular form. The most correct responses were given in response to an item requiring the inflection of make into its present participial form (25), and to that which required the formation of the negative of employment probably through prefixation (24). On the whole, the A-Sample reported 58 incorrect responses to 186 correct ones (a ratio of 3 correct responses to 1 error).

Table 3: The A-Sample's central tendency statistics

\begin{tabular}{|l|c|c|}
\hline \multicolumn{1}{|c|}{ Corrupted items and their expected correct responses } & Incorrect & Correct \\
\hline Present participle of make (making) & 0 & 25 \\
\hline Negative form of employment (unemployment) & 1 & 24 \\
\hline Past participle of underpin (underpinned) & 2 & 23 \\
\hline Adverb form of necessary (unnecessarily) & 4 & 21 \\
\hline Noun form of investigate (investigation) & 5 & 20 \\
\hline National curriculum statement as a proper noun (National Curriculum Statement) & 5 & 18 \\
\hline Demonstrative pronoun (those) & 6 & 17 \\
\hline Possessive form of model (model's) & 9 & 14 \\
\hline Third person singular form of view (views) & 12 & 13 \\
\hline Adjective formed from determinism (determinist[ic]) & 14 & 11 \\
\hline Mean test score out of 10 & & 7.44 \\
\hline Standard deviation & & 1.805 \\
\hline Median & 8.00 \\
\hline
\end{tabular}

As shown in Table 4, the SE-Sample had incorrect responses ranging from 7 to 41, and correct responses ranging from 1 to 36 . The most incorrect responses (41, 40 and 38) were to items requiring the repair of syntactic omission modifications (the insertion of the preposition with, and the adverbs very and rather,), as opposed to those requiring the fixing of morphological modifications. The most correct responses were to an item requiring proper noun capitalisation (36) and on that requiring the conversion of textual four to its ordinal form fourth. Two other items requiring the insertion of a demonstrative (those) post-modified by a relative clause, and of a conjunction (that), not the transformation of a modified word, got correct response rates of 17 of 25 (for those) and 28 out of 43 (for that), which suggested that the possible cause of a high number of incorrect responses might not have been the omission of words per se, but rather 
the omission of syntactically marginal or optional words. The peripheral status of the adverbs may have reduced their structural or textual recoverability. The incorrect responses on with highlighted the difficulty for the E-Sample of determining the accompaniment relationship being realised by the phrasal verb grow with in which the element with is compulsory. It was interesting that the scores on the two items in the SE-Sample requiring -ing inflection to form present participles from crush and cite had a difference of 10 points. An error analysis of the responses to crush (Table 6) revealed that some of the learners recognised the participial adjective function of the present participle as they replaced crushing with such morphologically unrelated but semantically related adjectives as huge and catastrophic, while one of the main issues with the responses to cite (Table 6) seemed to be spelling, the cause of which appeared to be the overgeneralisation of the double consonant rule (which had a frequency of 3 ), or just insufficient knowledge. There were 188 correct responses and 237 incorrect responses for the SE-Sample (a ratio of 1.2 errors to 1 correct response).

Table 4: The central tendency statistics of the SE-Sample

\begin{tabular}{|l|c|c|}
\hline \multicolumn{1}{|c|}{ Corrupted items and their expected correct responses } & Incorrect & Correct \\
\hline $\begin{array}{l}\text { New development bank as a proper noun } \\
\text { (New Development Bank) }\end{array}$ & 7 & 36 \\
\hline Ordinal form of numeral four (fourth) & 11 & 31 \\
\hline Insert conjunction (that) & 15 & 28 \\
\hline Present participle of crush (crushing) & 21 & 28 \\
\hline Possessive case of country (country's) & 24 & 18 \\
\hline Present participle of cite (citing) & 25 & 18 \\
\hline A noun-form of under-utilise (-utilisation) & 38 & 4 \\
\hline Insert correct adverb (rather) & 40 & 3 \\
\hline Insert adverb of emphasis (very) & 41 & 1 \\
\hline Insert correct preposition (with) & & 4.31 \\
\hline Mean score out of 10 & & 1.49 \\
\hline Standard deviation & & 4.00 \\
\hline Median & & 21 \\
\hline
\end{tabular}

\section{Error analysis of item responses}

Table 5 shows the error analysis results for the A-Sample, and Table 6, for the SE-Sample. Frequencies are provided in parentheses, next to the words.

\section{Proximal set}

This category consisted of words that were considered the closest to the expected correct response, and these were responses with spelling mistakes, those that were the expected correct grammatical category but the wrong form (particularly for morphological modifications) and 
those that were the same grammatical category but the wrong choice (for omission modifications, particularly). Capitalisation errors were also included under this category.

Mechanical errors: Only two types were possible: Orthographic (spelling) and capitalisation. The following words are examples of the misspelt words: underpined (2), neccessarily, models (2), utelisation. Initialisms of National Curriculum Statement and New Development Bank, NCS and NDB, were provided instead of the full words and initial capitals in each of them.

Table 5: Error analysis of the A-Sample, with frequencies in brackets

\begin{tabular}{|c|c|c|c|c|c|}
\hline \multirow{2}{*}{ Expected responses } & \multicolumn{3}{|c|}{ Grammatically incorrect responses } & \multirow{2}{*}{$\begin{array}{l}\text { Cancelled } \\
\text { responses }\end{array}$} & \multirow{2}{*}{$\begin{array}{c}\text { No } \\
\text { responses }\end{array}$} \\
\hline & Proximal set & Related set & Random set & & \\
\hline \multicolumn{6}{|l|}{ Making (25) } \\
\hline Unemployment (24) & & Unemployed & & & \\
\hline Underpinned (23) & underpined (2) & & & & \\
\hline Necessarily (21) & necessarily & $\begin{array}{l}\text { inevitable of } \\
\text { necessity, } \\
\text { necessitate } \\
\end{array}$ & enough & & \\
\hline Investigation (20) & $\begin{array}{l}\text { investigating } \\
\text { investigator (2) }\end{array}$ & pre-investigate & & & \\
\hline $\begin{array}{l}\text { National } \\
\text { Curriculum } \\
\text { Statement (18) }\end{array}$ & NCS & $\begin{array}{l}\text { CAPS policy, } \\
\text { Department of } \\
\text { Basic Education, } \\
\text { Courses }\end{array}$ & & CO, policy & NCS (2) \\
\hline Those (17) & People & $\begin{array}{l}\text { demonstrations } \\
\text { demonstrative }\end{array}$ & $\begin{array}{l}\text { it, though, } \\
\text { while }\end{array}$ & & those (2) \\
\hline Model's (14) & models (2) & $\begin{array}{l}\text { modelled, agent } \\
\text { modeler } \\
\text { modelling (2) } \\
\text { modelim }\end{array}$ & & modelised & model's (2) \\
\hline Views (13) & viewed (8) & $\begin{array}{l}\text { view's } \\
\text { view }\end{array}$ & $\begin{array}{l}\text { it } \\
\text { uncountable }\end{array}$ & viewed & \\
\hline $\begin{array}{l}\text { Deterministic } \\
\text { Determinist (11) }\end{array}$ & $\begin{array}{l}\text { determined (8) } \\
\text { determinable (2) } \\
\text { determining }\end{array}$ & determination (2) & & & \\
\hline
\end{tabular}

Word-form errors: The nouns investigator and investigating were provided instead of the correct noun investigation; similarly, the nouns utiliser (4), utilising (3), for utilisation; the past verb tense form viewed (8) instead of the third person present verb tense form views; while the adjectives determined (8), determinable (2), and determining were provided for deterministic or determinist. Despite being morphologically related to the same base verb, deterministic and determinist are not immediately related to the provided erroneous forms, and did not make sense as a substitute for the correct form.

Substitution or choice errors: The provision of these "substitute" responses was not the expected correct response, but was meaningful, and, in certain cases, grammatically acceptable, as well, and were, as a result accepted if they were the required form. Some of these responses might have been caused by the open-endedness of, or a lack of clarity in, some of the instructions. The substitution of people for the demonstrative pronoun those; that of quickly (3), 
increasingly (3), try (2), rapidly, mainly, voluntarily, therefore, correctly, and probably, for rather/instead; that of truly and sadly for very; and that of in (16), over (5), for (4) through, after, by (2), and besides, for with. Many of them, just as the expected correct response very, belonged to the adverb lexical category, or to the preposition category, in the case of the correct response with.

\section{Related set}

Grammatical category errors: This category contains responses that were morphologically related to the expected correct responses but were the incorrect grammatical category, such as the adjectival unemployed for the nominal unemployment; the verbal pre-investigate for the nominal investigation; the phrasal inevitable of necessity and the verbal necessitate for the adverbial necessarily; modelled, modeller, and modelling (2), for the genitive model's; genitive view's and nominal view, for verbal views; and nominal determination (2) for adjectival determinist or deterministic.

Semantic/pragmatic field errors: these are modifications that the respondents tried to repair by drawing on background knowledge of the situational or extralinguistic context, that is, with background knowledge from outside of the text. While the concept National Curriculum Statement (in full or abbreviated) evokes in SA curriculum policy jargon and context the concepts CAPS (Curriculum and Assessment Policy Statement), CAPS Policy, Department of Basic Education, and courses, these could not be provided to fix a capitalisation error in the context of this study. With agent and model, the respondents probably tapped into the modelling industry script, the core of which is the relationship between the two participants: the model and the modelling agency.

Instruction comprehension errors: Although the text-enhancement strategy of bolding was employed to foreground the form to be corrected, there were respondents who became confused, and consequently fixed the wrong item: for example, although "demonstrative pronoun" was bolded to show that the focus was not on the word demonstrative, some of the respondents still misunderstood the instruction and provided grammatical forms of demonstrative (demonstrations and demonstrative) instead of the required example of a demonstrative pronoun. A similar error was committed with "adverb of emphasis" wherein the following grammatical and lexical forms of the noun emphasis were given: emphasises (2), empathic (2), emphasising (7), emphasised (5), emphasized, emphasise, emphasize, and emphasisingly (4), instead of the required example of an adverb of emphasis. So with the phrase "correct adverb", where the forms of correct (correct, corrective and correcting) were also given instead of a suitable adverb example. 
Table 6: Error analysis of the SE-Sample, with frequencies (in brackets)

\begin{tabular}{|c|c|c|c|c|c|}
\hline \multirow{2}{*}{$\begin{array}{l}\text { Expected } \\
\text { responses }\end{array}$} & \multicolumn{3}{|c|}{ Grammatically incorrect responses } & \multirow{2}{*}{$\begin{array}{l}\text { Cancelled } \\
\text { responses }\end{array}$} & \multirow{2}{*}{$\begin{array}{c}\text { No } \\
\text { responses }\end{array}$} \\
\hline & Proximal set & Related set & Random set & & \\
\hline $\begin{array}{l}\text { New } \\
\text { Development } \\
\text { Bank (36) }\end{array}$ & $\begin{array}{l}\text { New development } \\
\text { bank (4) NDB }\end{array}$ & bank, banking & new, them, & $\begin{array}{l}\text { New } \\
\text { Development } \\
\text { Bank }\end{array}$ & \\
\hline Fourth (31) & $\begin{array}{l}\text { 4th (3) } \\
\text { forth (2) }\end{array}$ & 4 , fourty & forured, for (3) & forth, fourth & fourth \\
\hline That (28) & $\begin{array}{l}\text { and (4) } \\
\text { but (2) }\end{array}$ & so, if, as, & $\begin{array}{l}\text { in, countries, } \\
\text { becouse, with, } \\
\text { delegating, of ( } 2 \text { ) }\end{array}$ & that, highly & \\
\hline Crushing (28) & $\begin{array}{l}\text { crushed (2) } \\
\text { terrible, huge, } \\
\text { catastrophic, } \\
\text { crushable }\end{array}$ & $\begin{array}{l}\text { crush, crushis, } \\
\text { collide, crashed, } \\
\text { crushe, crusher, } \\
\text { crushes (4) }\end{array}$ & & & \\
\hline $\begin{array}{l}\text { Country's } \\
\text { (21) }\end{array}$ & $\begin{array}{l}\text { country', } \\
\text { countries (10) } \\
\text { contries, }\end{array}$ & $\begin{array}{l}\text { South African, } \\
\text { nation (2), } \\
\text { nation (South } \\
\text { Africa), his, } \\
\text { native, their, our } \\
\text { country, residing }\end{array}$ & & $\begin{array}{l}\text { country's, } \\
\text { people, } \\
\text { countries }\end{array}$ & country's \\
\hline Citing (18) & citting (3) & $\begin{array}{l}\text { cites (4) oncite, } \\
\text { cite, site ( } 2), \\
\text { citted, cited ( } 3), \\
\text { citement, incite }\end{array}$ & $\begin{array}{l}\text { cities, seeing, city, } \\
\text { state, cite's, says, } \\
\text { with }\end{array}$ & $\begin{array}{l}\text { citing, sit, cite, } \\
\text { cites }\end{array}$ & citing \\
\hline $\begin{array}{l}\text { Under- } \\
\text { utilisation } \\
(18)\end{array}$ & $\begin{array}{l}\text { utiliser (4) } \\
\text { utilising (3) } \\
\text { utelisation, }\end{array}$ & $\begin{array}{l}\text { utilised (2) use } \\
(2) \\
\text { utilize, utility, } \\
\text { utilises, used, } \\
\text { utilisement }\end{array}$ & $\begin{array}{l}\text { understanding, } \\
\text { mining, age (3), } \\
\text { it }(2) \text {, } \\
\text { underprivileged }\end{array}$ & $\begin{array}{l}\text { utiling, } \\
\text { utilises, utilities }\end{array}$ & \\
\hline $\begin{array}{l}\text { Rather/ } \\
\text { instead (4) }\end{array}$ & $\begin{array}{l}\text { quickly (3) } \\
\text { increasingly (3) } \\
\text { continuely, } \\
\text { rapidly, } \\
\text { voluntarily, just } \\
\text { highly, mostly }\end{array}$ & $\begin{array}{l}\text { corrective, } \\
\text { correct, mainly, } \\
\text { correcting, } \\
\text { correctly, } \\
\text { probably, }\end{array}$ & $\begin{array}{l}\text { also, can, must, } \\
\text { how to, therefore, } \\
\text { still, at least, and, } \\
\text { proceed to, start, } \\
\text { form, be getting, } \\
\text { over, even, have } \\
\text { to, try (2) }\end{array}$ & & rather \\
\hline Very (3) & $\begin{array}{l}\text { truly, sadly, } \\
\text { seriously }\end{array}$ & $\begin{array}{l}\text { emphasises (2) } \\
\text { empathic (2) } \\
\text { emphasising (7) } \\
\text { emphasised (5) } \\
\text { emphasized, } \\
\text { emphasise, } \\
\text { emphasive, } \\
\text { emphasize, } \\
\text { emphasisely, } \\
\text { emphasisingly } \\
\text { (4), emphasisly } \\
\text { emphasation } \\
\text { emphasiser }\end{array}$ & $\begin{array}{l}\text { powerful, } \\
\text { shocking, an, } \\
\text { sad/emotional, } \\
\text { cite, sad (3) }\end{array}$ & $\begin{array}{l}\text { utiling, } \\
\text { utilising, } \\
\text { emphasisers, } \\
\text { difficult }\end{array}$ & \\
\hline With (1) & $\begin{array}{l}\text { in (16), over (5), } \\
\text { for (4), through, } \\
\text { after }\end{array}$ & $\begin{array}{l}\text { every (2), by (2), } \\
\text { besides, grow, } \\
\text { smaller, higher }\end{array}$ & an, although, as & $\begin{array}{l}\text { between, } \\
\text { every }\end{array}$ & with \\
\hline
\end{tabular}

\section{Random set}

This set consisted of items with no apparent logical relation to the morphological and omission modifications, nor to the instructions in both the textual and situational context. It, though, and while do not seem to have any obvious relationship to those, nor does enough to necessary. 


\section{Cancelled set}

This category, which signified decision-making uncertainty, was made up of responses that were initially struck out in favour of alternatives. In some cases the crossed-out response happened to be the correct one, as in the replacement of that with for, of very with shocking and of country's with countries. In the last example it appeared as if the initial correct response was also suspected of having been misspelt, as was the case in a number of further examples, including the correction of the correct spelling of citing with the incorrectly spelt citting, or the correction of the incorrect spelling of fourth (forth) with the correct one (fourth). In a number of cases the incorrect struck-out word was replaced with the correct one, as with utilised for utilisation, policy for National Curriculum Statement and modelised for model's. In a number of other cases both the struck-out word and the replacement were incorrect, as in people and residing (for country's), difficult and powerful (for very), CO and NCS (for National Curriculum Statement), and view's and viewed (for views). Indecision errors, indicated by offering two responses instead of one, were also found with the correct pair of the numeral 4th and the textual fourth, and the incorrect pair of correct and corrective for rather/instead. Some of the scratched-out words were never replaced. These were emphasize (very), emphasizing (country's) and utilisation (fourth). Some more others were just mistakes of numbering where the response was written in the wrong space, for example, the response for 2.3 being written in 2.4, and then having to be scratched out and rewritten next to the correct number. What is noteworthy is that the majority of the struck-out responses were found in the SE-Sample, which had 25 of a potential minimum of 43, to the A-Sample's 4 of a potential minimum of 25 .

\section{No-response set}

This set consisted of "errors of omission", so to speak, and refers to cases in which the respondent attempted no response at all. The A-Sample had six frequencies relating to the following expected correct responses: National Curriculum Statement (2), those (2), and model's (2); while the SE-Sample had five: citing, country's, fourth, rather and with.

\section{Putative words or non-words}

In conclusion, there was a notable proportion of response items, mainly in the SE-Sample, whose status as English words is suspect. These are: crushis, modelim, modelised, emphasation, emphasisly, oncite, utilisement.

\section{Resistance to grammar instruction}

While the A-Sample appeared enthusiastically interactional and engaged with the lecturer and the content by asking questions and contributing comments, there was resistance from one 
student. The student, who identified as Afrikaans-speaking, and declared proficiency in English, in our one-on-one interviews, was much older and white, and had work experience of many years. The student held the view that grammar was difficult knowledge that he did not find valuable for himself, given his life and work experience. Notwithstanding this, the student completed the module without needing a supplementary examination, as the module was compulsory.

\section{CONCLUSIONS AND RECOMMENDATIONS}

The mean test score differences in this study suggest both that some extraneous variables, most obviously, the uncontrolled testing conditions for the assignment, were responsible for the variation in the performances of the two groups, and that the grammar instruction and error correction treatments probably had minimal to no effect at all. Since the SE-Sample test materials had more internal validity, the failure of the sample to attain a minimum mean test score of 50 per cent, the passing threshold for EAP, suggested that the sample could capitalise on neither the metalinguistic clues nor the meaning potential of the syntagmatic structure of the sentences to work out the correct responses.

The failure of the SE-sample to exploit the grammar and meaning systems should not suggest that the test was perfect. The fact that three of the most incorrect responses included two adverbs, which are optional elements that are also peripheral to clause structure (Quirk et al. 1985, 440) suggests that the inclusion of this kind of element in meaning-based tasks of this nature should be approached with caution. Because of their optionality and peripheralness in their adjective modification role (very), and as part of the clause structure (rather), adverbs (or adverbials) can be omitted without negatively affecting meaning or grammaticality, which may suggest that their inclusion in this test may not have offered the SE-sample optimal opportunity to exploit the meaning potential of the syntax. Moreover, as sometimes happens with input enhancement (Lee and Huang 2008), the meaning potential also appears to have been interfered with by the input enhancement and the pedagogical grammar clues, as evidenced by what we have termed instruction comprehension errors. Nevertheless, the performance of the SEsample should be concerning in that even though the mean test scores cannot be reflective of the performance of the EAP population because of the exclusion of members who passed the main examination, they do indicate probabilities of the presence of an EAP subpopulation that could not pass a very simple parts-of-speech grammar test regardless of any limitations in the test instruments, which points to probabilities of underpreparedness in the language of tuition. Meanwhile, the third-person singular present tense verb form proved as elusive to the A-Sample as it has been to many other ESL learner groups (Nndwamato 2017, 92; Chele 2015, 37-38; 
Molin 2020, 3-4) as it recorded the second highest number of errors. The item with the most errors in the A-Sample, converting determinism to deterministic, perhaps indicates that while the suffix -ism is classified as a common English noun suffix, the suffix used to form denominal adjectives from it may not be, and may therefore need extended exposure and repeated formfocused grammar instruction for acquisition to occur.

The notable presence of non-words, pseudo-words or putative words suggested a conspicuous level of hypothesising about the rules of English morphology was still very active. The observation data showed that the typical student in the SE-sample, the one who participated with apparent interest and enthusiasm, probably viewed the grammar instruction as valuable and worthwhile knowledge for themselves. While resistance to grammar instruction may seem racialised by even the single case in this study, this case should not be regarded as typical since measures of resistance to English language learning programmes have come from students of all races (Moyo and Mann 2021), although some of the resistance might have been because of these programmes lacking grammar content, as suggested by the findings of Huang (2011, as cited by O'Neill and Russell 2019, 43) and Schug and Le Cor $(2017,89)$. What should be investigated is its potential systemic relationship with hegemonic power structures, which may further disadvantage those without social capital, such as ESL learners.

\section{REFERENCES}

Basturkmen, H. 2017. ESP teacher education needs. Plenary speeches. Cambridge: Cambridge University Press. 1-13. https://doi.org/10.1017/S0261444817000398

Burt, M. K. 1975. Error analysis in the adult EFL classroom. TESL Quarterly 9(1): 5-363. https://www.jstor.org/stable/3586012 (Accessed 6 March 2020).

CHE see Council on Higher Education.

Chele, M. I. 2015. An analysis of subject agreement errors in English: The case of third year students at the National University of Lesotho. Ghana Journal of Linguistics 4(1): 32-40. https://www.ajol.info/index.php/gjl/article/view/119789/109247 (Accessed 03 August 2020).

Council on Higher Education. 2013. A proposal for undergraduate curriculum reform in South Africa: The case for a flexible curriculum structure. Discussion document. Pretoria: CHE. http://www.che. ac.za/sites/default/files/publications/Full_Report.pdf (Accessed 02 March 2019).

Dudley-Evans, T. and M. J. St. John. 1998. Developments in English for specific purposes: A multidisciplinary approach. Cambridge: Cambridge University Press.

Ellis, R. 2015. The importance of focus-on-form in communicative language teaching. Eurasian Journal of Applied Linguistics 1(2): 1-12. https://dergipark.org.tr/en/download/article-file/536717 (Accessed 2 March 2019).

Ellis, R. 2016. Focus-on-form: A critical review. Language Teaching Research 20(3): 405428. https://doi.org/10.1177/1362168816628627

Ellis, R. 2017. Position paper: Moving task-based language teaching forward. Language Teaching 50(4): 507-526. https://doi.org/10.1017/S0261444817000179.

Hendrickson, J. M. 1976. Error analysis and selective correction in the adult ESL classroom: An experiment. https://files.eric.ed.gov/fulltext/ED135260.pdf (Accessed 26 March 2020).

Krashen, S. D. 1982. Principles and practice in Second Language Acquisition. Internet edition. 
http://www.sdkrashen.com/content/books/principles_and_practice.pdf (Accessed 3 July 2020).

Lee, S. K. and H. T. Huang. 2008. Visual input enhancement and grammar learning: A meta-analytic review. Studies in Second Language Acquisition 30: 307-331. DOI: https://doi.org/10.1017/ S0272263108080479

Long, M. H. 1997. Focus-on-form in task-based language teaching. https://woucentral.weebly.com/ uploads/7/4/6/9/7469707/long_1997_intro_focus_on_form.pdf (Accessed 2 March 2019).

Molin, V. 2020. An error analysis of subject-verb agreement by Swedish learners of English: A corpusbased study of the difficulties surrounding subject-verb agreement for Swedish students. Bachelor's degree thesis. Faculty of Education and Business Studies. University of Gävle. https://www.diva-portal.org/smash/get/diva2:1416130/FULLTEXT01.pdf (Accessed 1 August 2020).

Moyo, J. and C. Mann. 2021. (Upcoming). Transformation and the influence of selected sociodemographic variables on the face validity of an Engineering English for Specific Purposes approach at a South African university. South African Journal of Higher Education 35(1).

Nndwamato, N. M. 2017. An analysis of written concord errors among Grade 12 First Additional Language learners in Vhembe district of Limpopo Province, South Africa. Master of Arts dissertation. The School of Human and Social Sciences. The University of Venda. https://pdfs.semanticscholar.org/aa3f/620045b474056c54f7c91479f38e8db6fa46.pdf (Accessed 1 August 2020).

O’Neill, R. and A. Russell. 2019. Stop! Grammar time: University students' perceptions of the automated feedback program Grammarly. Australasian Journal of Educational Technology 35(1): 42-56. https://doi.org/10.14742/ajet.3795

Pam, P. and L. Karimi. 2016. The effect of textual enhancement technique on incidental learning of idiomatic expressions of Iranian intermediate students. Theory and Practice in Language Studies 6(5): 1121-1127. http://dx.doi.org/10.17507/tpls.0605.28

Quirk, R., S. Greenbaum, G. Leech and J. Svartvik. 1985. A comprehensive grammar of the English language. Harlow: Longman.

Schug, D. and G. Le Cor. 2017. Towards a dynamic approach to analysing student motivation in ESP courses. In New developments in ESP teaching and learning research, ed. S. Whyte and C. Sarré, 73-92. France. https://hal.archives-ouvertes.fr/hal-01657477/file/NewDevelopmentsESP_CSSW 2017.pdf (Accessed 16 April 2019).

Sharwood Smith, M. A. 1993. Input enhancement in instructed SLA: Theoretical bases. Studies in Second Language Acquisition 15: 165-179. http://dx.doi.org/ 10.1017/S0272263100011943

Swain, M. and S. Lapkin. 1995. Problems in output and the cognitive processes they generate: A step towards second language learning. Applied Linguistics 16: 371-391. http://dx.doi.org/10.1093/ applin/16.3.371

Swain, M. 2007. The output hypothesis: Its history and its future. http://www.celea.org.cn/2007/ keynote/ppt/Merrill\%20Swain.pdf (Accessed 2 March 2020).

Touchie, H. Y. 1986. Second language learning errors their types, causes, and treatment. Japan Association of Language Teachers Journal 8(1): 75-80. http://jalt-publications.org/files/ pdf/jalt_journal/jj-8-1.pdf\#page=86 (Accessed 6 March 2020).

Weidemann, A. 2019. Definition and design: Aligning language interventions in education. Stellenbosch Papers in Linguistics Plus 56: 31-46. doi: 10.5842/56-0-782

Winke, P. M. 2013. The effects of input enhancement on grammar learning and comprehension: A modified replication of Lee (2007) with eye-movement data. Studies in Second Language Acquisition 35(2): 323-352. https://doi.org/10.1017/S0272263112000903 